http://dx.doi.org/10.1590/0370-44672019720004

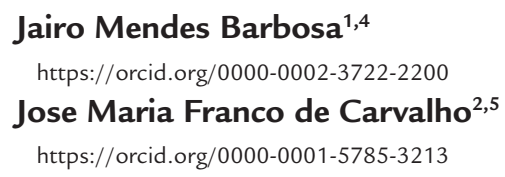

'Universidade Federal de Ouro Preto - UFOP, Escola de Minas, Departamento de Engenharia Civil, Ouro Preto - Minas Gerais - Brasil.

${ }^{2}$ Universidade Federal de Viçosa - UFV, Departamento de Engenharia Civil,

Viçosa - Minas Gerais - Brasil.

${ }^{3}$ Universidade Federal de Lavras - UFLA, Departamento de Engenharia,

Lavras - Minas Gerais - Brasil.

E-mails: ${ }^{4 j a i r o m e n d e s b @ y a h o o . c o m . b r, ~}$ 5josemaria.carvalho@ufv.br,

6keoma.silva@ufla.br, ${ }^{7}$ ricardofiorotti@ufop.edu.br, 8guilhermebrigolini@ufop.edu.br

\section{Influence of grinding on the pozzolanic activity of granite residue}

Abstract

This study explores the potential of the granite residue to be applied as a supplementary cementitious material. Furthermore, the efficiency of grinding methods in the improvement of the residue reactivity was also evaluated. The granite residue was collected in a facility located in Brazil and used as a Portland cement replacement with a substitution rate of $25 \%$ in mass. The residue was submitted to wet, dry and additive dry grinding methods, with several different times. The cement-based composites were characterized by quantitative X-Ray diffraction using the Rietveld's method, thermogravimetric analysis, and compressive strength. In conclusion, there was observed a higher efficiency of the wet grinding method, followed by an increase in compressive strength results as grinding time increased. Furthermore, the portlandite content was lower in the cement-based composite with granite residue, especially in the samples ground for 60, 120, and 180 minutes; a fact that summed up with other results for the pozzolanic potential of the granite residue.

Keywords: granite residue; grinding; supplementary cementitious materials; pozzolanic activity. 


\section{Introduction}

The granite mining and processing industries are a growing business area with an average growth in the world production of $6 \%$ per year in the last ten years. It is estimated that the stone industry moves around US\$ $80-100$ billion per year. Furthermore, forecasts point to a world stone production reaching 400 million tonnes per year (Menezes, et al., 2005; MME, 2009). The present strategy applied by the stone industry is to discharge all the residue in landfills or areas reserved for companies. However, the transport and dumping of residues in landfills involves substantial costs and serious environmental problems.

A variety of by-products including blast furnace slag (Cerulli, et al., 2003), rock wool waste (Defáveri, et al., 2018),

\section{Materials and methods}

A granite residue (GR) provided by a facility located in Ouro Preto, MG, Brazil, was used in this research. The material was obtained from two production stages (cutting and fly ash (Li and Wu, 2005), sugarcane bagasse ash (Cordeiro, et al., 2008), among others, have been effectively tested in cement-based composites, improving mechanical and chemical properties as well as environmental gains. The Portland cement industry has the capacity to absorb a huge volume of by-products; a fact that yields several advantages: environmental by the recycling of by-products; reduction of natural resources extraction; reduction of anthropogenic greenhouse gas associated with the production of cement clinker; and cement-based products with better properties than ordinary composites (Ihask and Hashim, 2015; Miller, 2018).

Recent studies have shown the potential of granite residue for application in the construction industry, such as vi- able composite blocks based on Portland cement; granite and marble residue for residential construction (Souza, et al., 2017); quarry granitic sludge residue as SCM for cement mortar, promoting a denser matrix with a $70 \%$ improvement in resistance to chlorides (Ramos, et al., 2013); and material suitable for replacing natural raw material in tile production (Torres, et al., 2009).

Herein, a study on the utilization of granite residue as supplementary cementitious material on mortars is presented, along with its pozzolanic activity improvement by mechanical treatment. For this purpose, we considered different grinding methods and times, and performed an extensive characterization program on the raw and processed materials.

\subsection{GR processing and characterization}

The grinding programs were performed in a planetary ball mill Retsch PM 100 , using a $500 \mathrm{~mL}$ zirconia pot and zirconia balls $(120 \mathrm{~mL}$, diameters 5,10 , and polishing). The muds were collected representatively, air-dried, and stored in sealed plastic containers.

A high early strength cement was used in the production of cement

pastes and mortars. This cement is specified by the Brazilian standard NBR 5733 (ABNT, 1991) as CP-V type. Natural quartz sand was used in this research.

$20 \mathrm{~mm}$ ). The volume of processed material per cycle was $80 \mathrm{~g}$. Two grinding routes were evaluated: wet grinding and dry grinding. A dry grinding program using

\begin{tabular}{c|c|c|c} 
Grinding time (min.) & Dry route & Dry route with additive & Wet route \\
\hline 5 & $\mathrm{X}$ & - & $\mathrm{X}$ \\
\hline 15 & $\mathrm{X}$ & - & $\mathrm{X}$ \\
\hline 30 & $\mathrm{X}$ & $\mathrm{X}$ & $\mathrm{X}$ \\
\hline 60 & $\mathrm{X}$ & $\mathrm{X}$ & $\mathrm{X}$ \\
\hline 120 & $\mathrm{X}$ & $\mathrm{X}$ & $\mathrm{X}$ \\
\hline 180 & - & $\mathrm{X}$ & $\mathrm{X}$ \\
\hline
\end{tabular}

The physical characterization comprised: particle size distribution (laser diffraction, Bettersize2000); density (Le Chatelier flask method); and BET specific surface area (NOVA 1200e). For evaluation of the grinding efficiency, the control parameters were the time, and the characteristic particle sizes D50 and D90, obtained by the particle size analyses (where $\mathrm{DN}$ is the opening of a theoretical sieve, through which N\% of the particles passes).

The chemical characterization comprised: semi-quantitative analysis by XRF (PANalytical Epsilon3x); and punctual chemical composition by scanning electron microscopy with energy dispersive spectrometry (SEM/EDS) (TESCAN VEGA 3, and backscattered electron image). The XRF analysis was performed in a powdery sample, smashed in an agate mortar and passing through the \#200 sieve. The SEM images were performed in raw and ground samples, embedded in epoxy resin and carbon coated.

The mineralogical phases of the GR were identified and quantified by QXRD a glycol-based grinding additive was also performed, and the wet-grinding liquid was isopropyl alcohol. Table 1 shows the grinding times and routes used in this research.

Table 1

Grinding times and

routes used in this research.

using the Rietveld refinement. A Bruker D2 Phaser device was used to obtain the diffractograms $(\mathrm{CuK} \alpha$ radiation; $15 \mathrm{~mA}$; $30 \mathrm{kV}$; step size $0.02^{\circ} \theta$; 0.8 s step time; $5-70^{\circ} 2 \theta$ range). The identification and quantification of mineral phases were carried out using the software Topas and the ICDD PDF4+ database. Fluorite $\left(\mathrm{CaF}_{2}\right)$ was used as internal standard (10 wt $\%$, homogenization in an agate mortar for $10 \mathrm{~min})$. The XRD was performed in a powdery sample, using the analogous method as presented for $\mathrm{XRF}$ analysis. 


\subsection{Production and evaluation of the GR-modified cement pastes}

A reference cement paste and modified pastes with $25 \mathrm{wt} \%$ cement replacement by GR fines were prepared. The mixture was performed manually for 5

Table 2

GR pastes produced and evaluated in this research.

Samples were taken from the produced pastes at the ages of 28 and 56 days, in order to perform the thermal and QXRD analyses. The samples were crushed by hand using the agate mortar until they had passed entirely through the \#200 sieve. The equipment, setups, software and database used were the same as minutes. $\mathrm{Na}_{2} \mathrm{SO}_{3}$ (4\% of cement weight) was evaluated as an activator of the pozzolanic reactions. The cement pastes were molded in plastic molds and sealed with a
PVC film. The samples were maintained in a wet chamber for 28 and 56 days (99\% $\left.\mathrm{RH}, 40{ }^{\circ} \mathrm{C}\right)$. Table 2 shows the pastes mixture details.

\begin{tabular}{c|c|c|c|c|c} 
Paste & Cement $(\mathrm{g})$ & $\mathrm{GR}(\mathrm{g})$ & Grinding time $(\mathrm{min})$. & Water $(\mathrm{g})$ & $\mathrm{Na}_{2} \mathrm{SO}_{4}(\%)^{*}$ \\
\hline REF & 500 & 0 & - & 250 & - \\
\hline GRP & 375 & 125 & 0 & 250 & - \\
\hline GPR30 & 375 & 125 & 30 & 250 & - \\
\hline GPR60 & 375 & 125 & 60 & 250 & - \\
\hline GPR120 & 375 & 125 & 120 & 250 & - \\
\hline GPR180 & 375 & 125 & 180 & 250 & - \\
\hline REF-Na & 500 & 0 & - & 250 & 4.0 \\
\hline GRP-Na & 375 & 125 & 0 & 250 & 4.0 \\
\hline GPR30-Na & 375 & 125 & 30 & 250 & 4.0 \\
\hline GPR60-Na & 375 & 125 & 60 & 250 & 4.0 \\
\hline GPR120- $\mathrm{Na}$ & 375 & 125 & 120 & 250 & 4.0 \\
\hline GPR180- $\mathrm{Na}$ & 375 & 125 & 180 & 250 & 4.0 \\
\hline & & &
\end{tabular}

previously described.

Quantification of the portlandite and calcite in the hydrated GR-modified Portland cement pastes, aged 28 and 56 days, was also performed by TG analyses. For this purpose, a Shimadzu DTG$60 \mathrm{H}$ device was used, and the following conditions were adopted: $5 \mathrm{mg}$ sample weight; $25-1000{ }^{\circ} \mathrm{C}$ temperature range; $10^{\circ} \mathrm{C} / \mathrm{min}$ heating rate; and inert $\mathrm{N}_{2}$ atmosphere $(50 \mathrm{~mL} / \mathrm{min}$ flow rate). For the calculations, the expression $\mathrm{CH}=(4 / 3) \cdot\left(4.11 \cdot \mathrm{M}_{\mathrm{CH}}\right)$ was used, where: $\mathrm{CH}$ is the portlandite content; $4 / 3$ is a factor that considers the dilution effect; and $M_{C H}$ is the weight loss due to the dehydroxylation of portlandite.

\subsection{Production and evaluation of the GR-modified cement mortars}

A reference cement mortar and GRmodified cement mortars $(25 \mathrm{wt} \%$ cement replacement by GR fines) were produced as shown in Table 3.
Table 3

GR mortars produced and evaluated in this research.

The consistency of the mortar was adjusted to be close to $210 \mathrm{~mm}$ in the flow table test. A superplasticizer admixture

\begin{tabular}{c|c|c|c|c|c|c|c} 
Mortar & $\begin{array}{c}\text { Standard } \\
\text { sand (g) }\end{array}$ & $\begin{array}{c}\text { Cement } \\
(\mathrm{g})\end{array}$ & $\begin{array}{c}\text { GR } \\
(\mathrm{g})\end{array}$ & $\begin{array}{c}\text { Grinding } \\
\text { time (min) }\end{array}$ & $\begin{array}{c}\text { Water } \\
(\mathrm{g})\end{array}$ & $\begin{array}{c}\mathrm{Na}_{2} \mathrm{SO}_{4} \\
(\%)^{*}\end{array}$ & $\begin{array}{c}\text { Admixture } \\
(\%)^{*}\end{array}$ \\
\hline REF & 1872 & 624 & 0 & - & 250 & - & 1.6 \\
\hline GRM & 1872 & 468 & 125 & 0 & 250 & - & 1.6 \\
\hline GRM30 & 1872 & 468 & 125 & 30 & 250 & - & 1.6 \\
\hline GRM60 & 1872 & 468 & 125 & 60 & 250 & - & 1.6 \\
\hline GRM120 & 1872 & 468 & 125 & 120 & 250 & - & 1.6 \\
\hline GRM180 & 1872 & 468 & 125 & 180 & 250 & - & 1.6 \\
\hline REF-Na & 1872 & 468 & 0 & - & 250 & 4.0 & 6.4 \\
\hline GRM-Na & 1872 & 468 & 125 & 0 & 250 & 4.0 & 6.4 \\
\hline GRM30-Na & 1872 & 468 & 125 & 30 & 250 & 4.0 & 6.4 \\
\hline GRM60-Na & 1872 & 468 & 125 & 60 & 250 & 4.0 & 6.4 \\
\hline GRM120-Na & 1872 & 468 & 125 & 120 & 250 & 4.0 & 6.4 \\
\hline GRM180-Na & 1872 & 468 & 125 & 180 & 250 & 4.0 & 6.4 \\
\hline
\end{tabular}

(McBauchemie, Powerflow4000) was used to provide the required consistency.

The pozzolanic activity index (PAI) of the mortars was determined according to the NBR 5752 (ABNT, 2014) standard. For this purpose, $6 \varnothing 50 \times 100 \mathrm{~mm}$ cylindrical 
specimens were molded for each tested mortar, as prescribed by the NBR 7215 (ABNT, 1996). The specimens were demolded after being aged $24 \mathrm{~h}$ (without $\mathrm{Na}_{2} \mathrm{SO}_{3}$ ) and $48 \mathrm{~h}$ (with $\mathrm{Na}_{2} \mathrm{SO}_{3}$ ), and maintained immersed

\section{Results and discussion}

\subsection{Grinding evaluation}

Figure 1 shows the evolution of the particle-size parameters D50 and D90 through the grinding programs and times for the tested ground GRs. Better efficiency in dry route was observed for

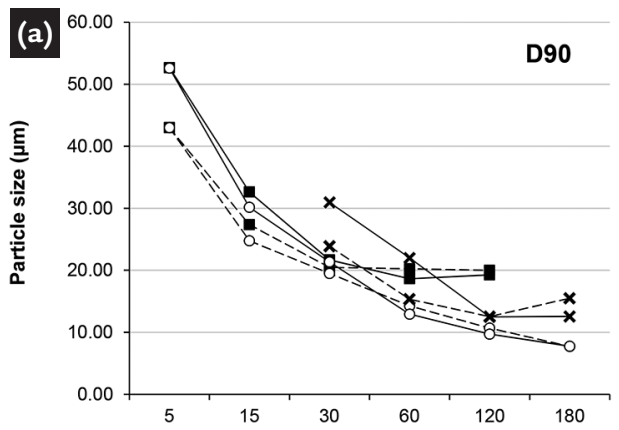

Grinding time (min.)

The D90 curves showed higher slopes, mainly for grinding times greater than 30 minutes, which shows that the grinding process was more effective in larger particles. Small particles exhibit a tendency to deform plastically instead of dividing into smaller ones (Flores, 2010). For the use of the grinding additive in dry grinding, the following behaviors were observed: reduction in the particle sizes in lime-saturated water until the test $(28$ days). The compressive tests were performed in sulfur-capped specimens, using an EMIC PC20000 universal test machine (200 kN load cell, 0.25 MPa/s load speed).
The water absorption of the same specimens was measured by the immersion method NBR 9778 (ABNT, 2005). Six specimens were used for each determination. cutting and polishing residues, for grinding times lower than 30 minutes. For grinding times greater than 60 minutes, the polishing residue ground in wet route obtained better results. These finds are

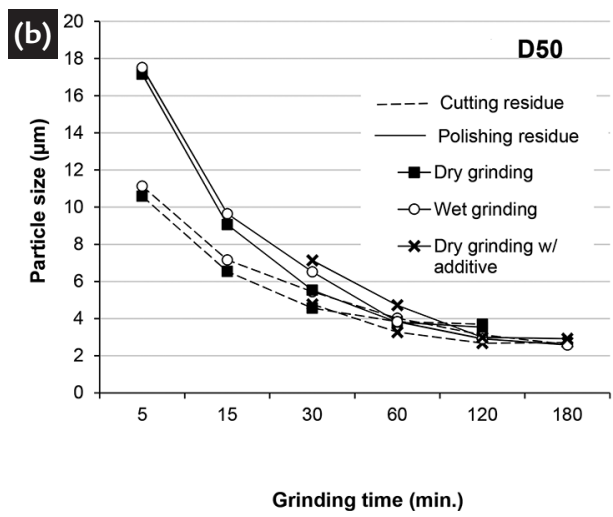

(except D90 for $180 \mathrm{~min}$ ); smaller D50 for cutting residues at 30 minutes grinding time and a tendency towards equalizing for times greater than 60 minutes; and loss of grinding efficiency from 120 minutes in both polishing and cutting residue. Furthermore, the steel shot content in the cutting granite residue interfered in the grinding efficiency due to its ductility and toughness. For this reason, from this point in good agreement with those reported by Kotake et al. (2011), showing that the particle agglomeration is inhibited in wet grinding, increasing the efficiency and obtaining smaller particle sizes.

\subsection{Physical, chemical and mineralogical characterization of the GR fines}

Table 4 shows the physical characteristics of the GR fines produced in this research.

\begin{tabular}{|c|c|c|c|c|c|c|c|}
\hline \multirow[t]{2}{*}{ Product } & \multirow{2}{*}{$\begin{array}{l}\text { Grinding } \\
\text { time (min.) }\end{array}$} & \multirow{2}{*}{$\begin{array}{l}\text { Grinding } \\
\text { route }\end{array}$} & \multicolumn{3}{|c|}{$\begin{array}{l}\text { Particle size } \\
\qquad(\mu \mathrm{m})\end{array}$} & \multirow{2}{*}{$\begin{array}{l}\text { Density } \\
\left(\mathrm{g} / \mathrm{cm}^{3}\right)\end{array}$} & \multirow{2}{*}{$\begin{array}{c}\text { Specific surface } \\
\text { area }\left(\mathrm{m}^{2} / \mathrm{g}\right)\end{array}$} \\
\hline & & & D10 & D50 & D90 & & \\
\hline Raw GR & 0 & Dry & 3.35 & 25.75 & 85.29 & 2.71 & 5.531 \\
\hline GR30 & 30 & Dry & 1.13 & 5.53 & 21.67 & 2.71 & 4.332 \\
\hline GR60 & 60 & Wet & 1.06 & 3.84 & 12.92 & 2.70 & 6.201 \\
\hline GR120 & 120 & Wet & 0.95 & 2.92 & 9.70 & 2.70 & 7.386 \\
\hline GR180 & 180 & Wet & 0.90 & 2.58 & 7.75 & 2.71 & 8.914 \\
\hline
\end{tabular}

Reduction in the particle sizes was observed for all programs, but the GR180 showed best results with D90 reaching $8 \mu \mathrm{m}$. A continuous well-graded distribution for the raw GR was observed, but the grinding process produced distributions tending to be more uniform when increasing the grinding time. The mechanical treatment promoted particle sizes significantly smaller, meeting the requirements of the standard NBR 12653 (ABNT, 2015) for pozzolanic materials (D66 $\leq 45 \mu \mathrm{m})$. Additionally, values for D50 less than $5 \mu \mathrm{m}$ for GR60, GR120,
Figure 1

Characteristic particle sizes of the ground GRs for different grinding times and routes: (a) D90; (b) D50.

on, the cutting residue will no longer be considered in this research.

Based on the grinding results, the grinding times adopted in the production of the GR fines used in this research were 0 (smashing), 30,60, 120, and 180 minutes. The dry route was used for smashing process and 30 minutes grinding. For the other grinding times, the wet route was chosen.
Table 4

Physical characteristics of the GR fines produced in this research.

and GR180 were observed, enabling the fulfillment of capillary voids in cement-composite matrices, and the improvement of the homogenization in the interfacial transition zone (Mehta and Monteiro, 2006).

The grinding time increased the 
specific surface area, reaching $8.914 \mathrm{~m}^{2} / \mathrm{g}$ for 180 minutes of grinding time. The high specific surface area facilitates the contact with the solution and with the $\mathrm{Ca}^{+}$ion improving the reactivity (Cincotto, 2011).

Benezet and Benhassaine (1999) argue that the particle size and the specific surface area influence in the reactivity and reaction speed. Smaller particles and higher specific surface areas increase the

Figure 2

SEM/BSE imagens:

(a) raw GR; (b) GR60; (c) GR180.

The sum of silicon, aluminum and iron oxides corresponds to $85.9 \%$, exceeding the minimum required for pozzolanic materials $(70 \%)$, as prescribed by NBR 12653 (ABNT, 2015). The alkali contents $\left(\mathrm{K}_{2} \mathrm{O}\right.$ and $\left.\mathrm{Na}_{2} \mathrm{O}\right)$ exceed the recommendation of NBR 12653 (ABNT, 2015) for pozzolanic materials $\left(\leq 1.5 \%\right.$ of $\left.\mathrm{Na}_{2} \mathrm{O}\right)$. Thus, the GR waste will contribute to the increase of the alkali contents in GRmodified cements, which will require attention for the risk of expansion for possible reactions with reactive aggregates in the hardened concrete (Mehta and hydration rate. Although, for this to occur, the achievement of a critical particle size and a specific surface area is required. For ground quartz, the critical values are $5 \mu \mathrm{m}$ and $1.0 \mathrm{~m}^{2} / \mathrm{g}$, respectively (Benezet and Benhassaine, 1999). In this way, the GR fines achieved these requirements.

The RG presented a chemical composition consistent with granitic rocks, with high $\mathrm{SiO}_{2}$ content $(68.5 \%)$, moderate $\mathrm{Al}_{2} \mathrm{O}_{3}$
(13.1\%), considerable $\mathrm{K}_{2} \mathrm{O}, \mathrm{Fe}_{2} \mathrm{O}_{3}, \mathrm{CaO}$ and $\mathrm{Na}, \mathrm{O}(5.1 \%, 4.3 \%, 4.1 \%$, and $3.7 \%$ respectively), and traces of $\mathrm{MgO}, \mathrm{P}_{2} \mathrm{O}_{5}$ and $\mathrm{TiO}_{2}$. The XRF results are consistent to those observed in the SEM/EDS punctual analyses, where the predominance of particles rich in $\mathrm{Si}, \mathrm{O}, \mathrm{Al}$ and $\mathrm{K}$ were observed, along with some few particles rich in $\mathrm{Fe}$ and $\mathrm{O}$. Figure 2 shows the SEM/BSE images with indications of punctual chemical compositions.

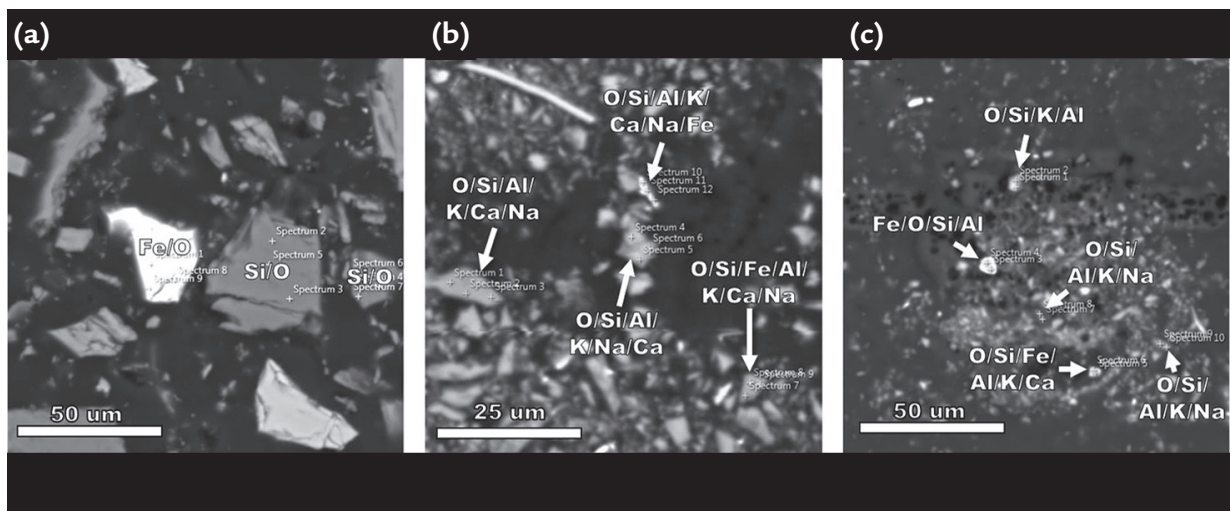

Monteiro, 2006).

The results of the QXRD analysis by Rietveld's method are shown in Figure 3. The main crystalline phases observed in the GR fines were quartz $\left(\mathrm{SiO}_{2}\right)$ and calcite $\left(\mathrm{CaCO}_{3}\right)$. Peaks related to albite $\left(\mathrm{NaAlSi}_{3} \mathrm{O}_{8}\right)$, biotite $\left[\mathrm{K}(\mathrm{Mg}, \mathrm{Fe})_{3}\left(\mathrm{AlSi}_{3} \mathrm{O}_{10}\right)(\mathrm{F}, \mathrm{OH})_{2}\right]$, cordierite $\left[\mathrm{Al}_{3}(\mathrm{Mg}, \mathrm{Fe})_{2} \mathrm{Si}_{5} \mathrm{AlO}_{18}\right]$ and orthoclase $\left(\mathrm{KAlSi}_{3} \mathrm{O}_{8}\right.$ ) were also observed in the QXRD diffractograms. The chemical composition of the mineralogical phases observed is in good agreement with the $\mathrm{XRF}$ and SEM/EDS results.
There was an increase in the amorphous content for the fines GR30, GR60, GR120, and GR180 compared to raw GR. The best results were observed for GR120, with an amorphous content of $10.3 \%$. This result is better than that observed by Flores (2010) (8.79\%), even with higher values for D90. The higher amorphous contents indicate that the grinding energy applied in the material led to a crystallinity reduction, indicating an increase in the reactivity by the formation of active surfaces (Palaniandy, et al., 2007).

Figure 3

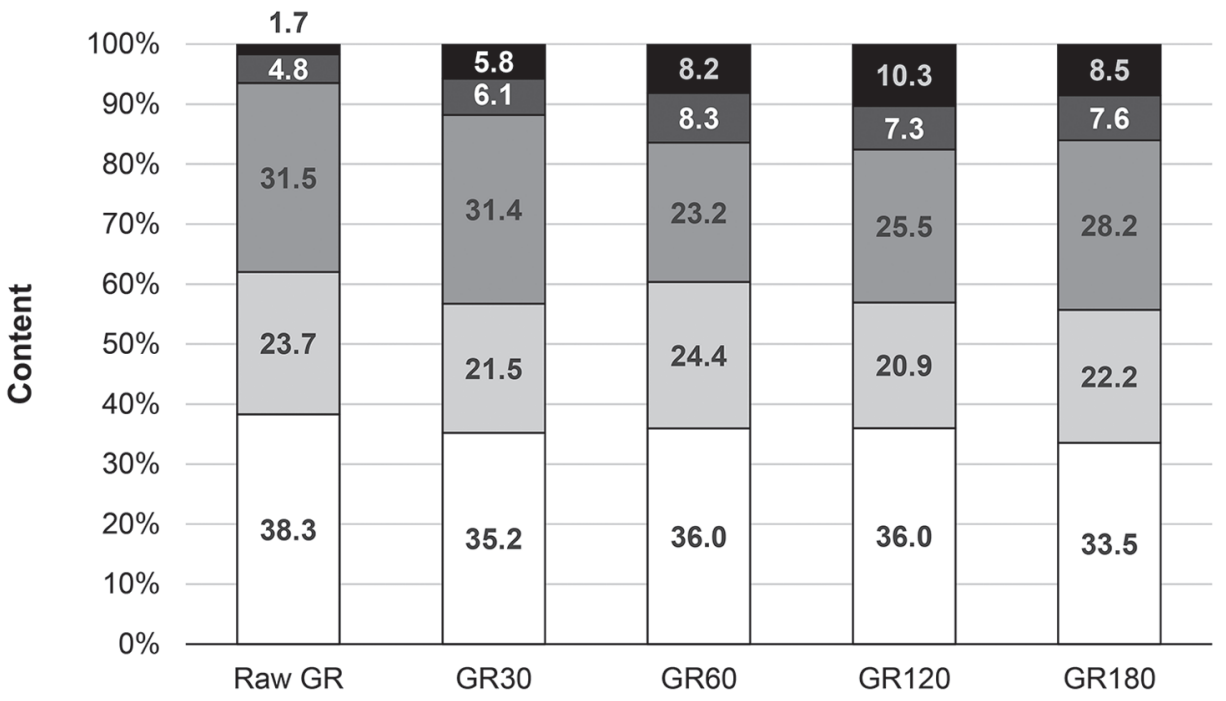

Results of the QXRD

analysis for the evaluated GR fines.

घAmorphous $\square$ Others (Biotite. Calcite and Cordierite) $\square$ Ortoclase $\square$ Albite $\square$ Quartz

\subsection{Evaluation of the GR-modified cement pastes}

Table 5 presents the values of weight loss in the interest ranges. 


\begin{tabular}{|c|c|c|c|c|}
\hline \multirow{2}{*}{ Paste } & \multirow{2}{*}{$\begin{array}{c}\text { Age } \\
\text { (days) }\end{array}$} & \multicolumn{3}{|c|}{ Weight loss for temperature range (related phases) (\%) } \\
\hline & & $0-100{ }^{\circ} \mathrm{C}\left(\right.$ Free $\left.\mathrm{H}_{2} \mathrm{O}\right)$ & $400-460{ }^{\circ} \mathrm{C}$ (Portlandite) & $600-700{ }^{\circ} \mathrm{C}\left(\mathrm{CaCO}_{3}\right)$ \\
\hline REF & 28 & 13.35 & 3.96 & 2.24 \\
\hline GRP & 28 & 14.58 & 3.92 & 1.89 \\
\hline GRP30 & 28 & 15.36 & 3.94 & 2.34 \\
\hline GRP60 & 28 & 15.85 & 3.91 & 2.74 \\
\hline GRP120 & 28 & 15.97 & 3.90 & 2.84 \\
\hline GRP180 & 28 & 14.98 & 3.82 & 2.53 \\
\hline REF-Na & 28 & 13.68 & 3.72 & 1.92 \\
\hline GRP-Na & 28 & 14.92 & 3.67 & 1.90 \\
\hline GRP30-Na & 28 & 14.56 & 3.51 & 1.91 \\
\hline GRP60-Na & 28 & 15.13 & 3.14 & 1.87 \\
\hline GRP120-Na & 28 & 13.35 & 2.99 & 1.89 \\
\hline GRP180-Na & 28 & 12.48 & 2.94 & 1.94 \\
\hline REF & 56 & 12.12 & 4.62 & 2.64 \\
\hline GRP & 56 & 15.18 & 4.18 & 2.78 \\
\hline GRP30 & 56 & 14.93 & 4.29 & 3.38 \\
\hline GRP60 & 56 & 16.03 & 4.22 & 2.85 \\
\hline GRP120 & 56 & 15.59 & 4.21 & 2.76 \\
\hline GRP180 & 56 & 14.62 & 4.02 & 2.67 \\
\hline REF-Na & 56 & 13.89 & 4.37 & 2.62 \\
\hline GRP-Na & 56 & 15.22 & 4.33 & 2.35 \\
\hline GRP30-Na & 56 & 16.02 & 4.18 & 2.47 \\
\hline GRP60-Na & 56 & 16.17 & 4.01 & 2.36 \\
\hline GRP120-Na & 56 & 15.82 & 3.91 & 2.43 \\
\hline GRP180-Na & 56 & 16.05 & 3.79 & 2.57 \\
\hline
\end{tabular}

The first peak occurs below $100{ }^{\circ} \mathrm{C}$, followed by an approximate constant weight loss related to the dehydration process $\left(100-300{ }^{\circ} \mathrm{C}\right)$. The second peak occurs at $400-460^{\circ} \mathrm{C}$ related to the dehydroxylation of the $\mathrm{Ca}(\mathrm{OH})_{2}$. In the range $600-700{ }^{\circ} \mathrm{C}$, two peaks were observed in some cases related to the decarbonation of the $\mathrm{CaCO}_{3}$. The decomposition of this phase can occur in more than one temperature range, due to the presence of metastable calcium carbonate (aragonite and vaterite), or $\mathrm{CaCO}_{3}$ with a lesser crystallization grade (Fang and Chang, 2015).

The evaluation of the portlandite consumption indicates that the pastes without $\mathrm{Na}_{2} \mathrm{SO}_{4}$ aged 28 days presented a reduced portlandite content for GRP120 and GRP180 compared to REF. For the pastes aged 56 days without $\mathrm{Na}_{2} \mathrm{SO}_{4}$, all

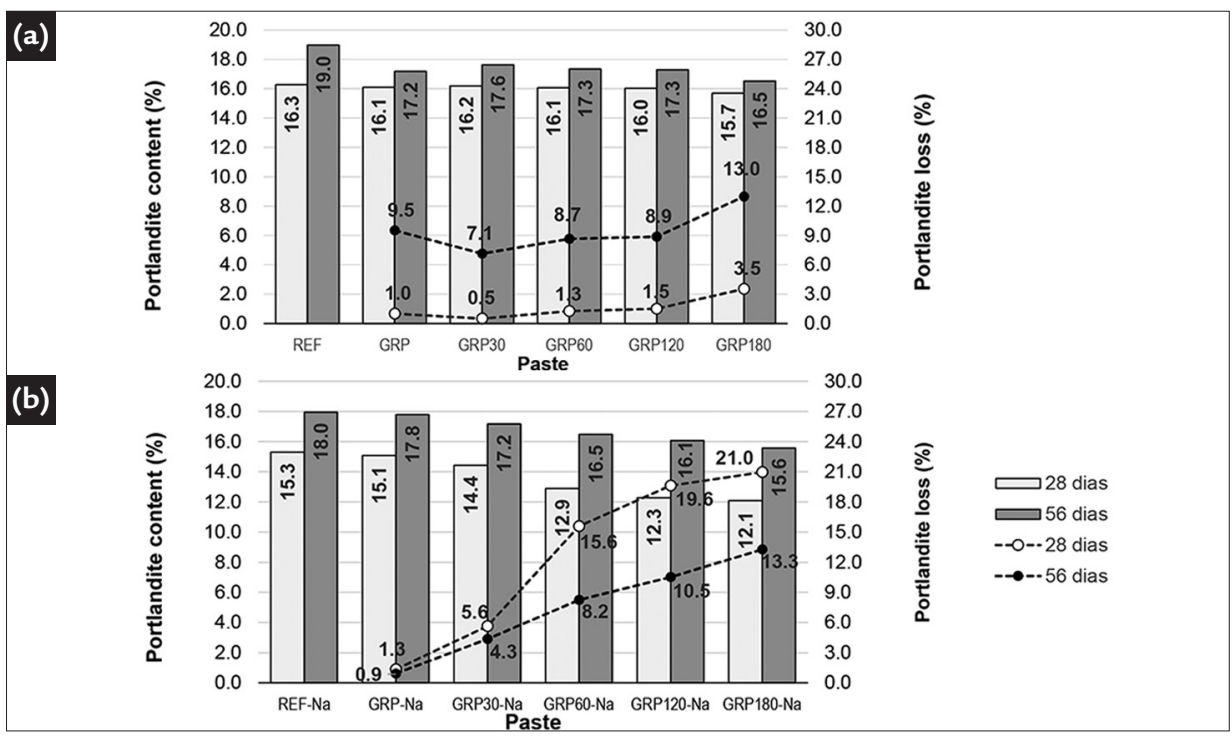

Table 5

Weight loss of the cement pastes in the interest temperature ranges.

the samples achieved reduced portlandite content when compared to REF. Regarding the $\mathrm{Na}_{2} \mathrm{SO}_{4}$ pastes aged 28 days, the samples GRP60-Na, GRP120-Na and GRP180-Na achieved a reduced portlandite compared to REF-Na, while all $\mathrm{Na}_{2} \mathrm{SO}_{4}$ pastes aged 56 days achieved a reduced portlandite content compared to REF-Na. The results of the portlandite content are shown in Figure 4.
Figure 4

Portlandite content in the studied cement pastes aged 28 and 56 days: (a) Pastes without $\mathrm{Na}_{2} \mathrm{SO}_{4}$; (b) pastes with $\mathrm{Na}_{2} \mathrm{SO}_{4}$. 
The decrease in the portlandite content in the cement pastes indicates the occurrence of the pozzolanic activity. The highest consumptions observed at 56 days are in good agreement with literature, which reports that pozzolanic activities develop mainly in late ages, leading to an increase in the available C-S-H content, and a decrease in the portlandite content (Mehta and Monteiro, 2006).
Table 6 shows the results of the QXRD analyses of the cement pastes. These results showed higher amounts of portlandite for 56 days in the pastes REF and GRP30, compared to the same pastes aged 28 days. The amount of portlandite was similar for the pastes GRP and GRP60 for both 28 and 56 days. However, the pastes GRP120 and GRP180 aged 56 days, showed a decrease in the portlandite content compared to the same pastes aged 28 days. These observations indicate pozzolanic activity in the pastes GRP120 and GRP180, but more significant in this last one. The increase in the amorphous content in these two pastes corroborates with these observations, indicating the reaction of the portlandite with silica and formation of C-S-H gel or other phases not identifiable by the XRD (Allahverdi and Ghorbani, 2006).

\begin{tabular}{|c|c|c|c|c|c|c|c|c|}
\hline Paste & $\begin{array}{c}\text { Age } \\
\text { (days) }\end{array}$ & $\begin{array}{l}\text { Portlandite } \\
\text { (\%) }\end{array}$ & $\begin{array}{c}\text { Calcite } \\
(\%)\end{array}$ & $\begin{array}{l}\mathrm{C}_{3} \mathrm{~S} \\
(\%)\end{array}$ & $\begin{array}{l}\mathrm{C}_{2} \mathrm{~S} \\
(\%)\end{array}$ & $\begin{array}{c}\text { Hemi/mono- } \\
\text { carboaluminate } \\
(\%)\end{array}$ & $\begin{array}{c}\text { Ettringite } \\
(\%)\end{array}$ & $\begin{array}{c}\text { Amorphous } \\
(\%)\end{array}$ \\
\hline \multirow{2}{*}{ REF } & 28 & 13.2 & 5.8 & 1.9 & - & 0.4 & 5.6 & 71.2 \\
\hline & 56 & 13.8 & 3.4 & 1.6 & 0.4 & 3.4 & 6.1 & 70.5 \\
\hline \multirow{2}{*}{ GRP } & 28 & 13.6 & 2.2 & 0.7 & 0.2 & 1.2 & 6.1 & 75.3 \\
\hline & 56 & 13.5 & 4.7 & 2.1 & 0.6 & 5.1 & 6.7 & 63.2 \\
\hline \multirow{2}{*}{ GRP30 } & 28 & 11.6 & 7.3 & 1.9 & 0.7 & 4.4 & 7.6 & 66.3 \\
\hline & 56 & 14.2 & 5.0 & 1.2 & 0.9 & 5.3 & 6.3 & 69.1 \\
\hline \multirow{2}{*}{ GRP60 } & 28 & 11.9 & - & 1.6 & 0.9 & 3.4 & 4.6 & 68.7 \\
\hline & 56 & 11.8 & 1.8 & 2.0 & 0.5 & 4.1 & 5.2 & 79.9 \\
\hline \multirow{2}{*}{ GRP120 } & 28 & 10.8 & 3.6 & 1.8 & 0.5 & 4.4 & 5.1 & 80.9 \\
\hline & 56 & 10.2 & 2.0 & 2.0 & 0.6 & 4.5 & 6.4 & 78.8 \\
\hline \multirow{2}{*}{ GRP180 } & 28 & 11.2 & 4.2 & 1.8 & 0.7 & 3.9 & 5.8 & 80.5 \\
\hline & 56 & 9.0 & 3.1 & 1.9 & 0.3 & 3.6 & 4.2 & 90.3 \\
\hline \multirow{2}{*}{ REF-Na } & 28 & 10.6 & 5.1 & 2.3 & 0.5 & 3.0 & 3.7 & 72.4 \\
\hline & 56 & 13.4 & 3.1 & 2.1 & 0.7 & 3.2 & 6.1 & 70.3 \\
\hline \multirow{2}{*}{ GRP-Na } & 28 & 12.0 & 3.1 & 2.1 & 0.4 & 3.5 & 7.6 & 78.1 \\
\hline & 56 & 8.9 & 4.2 & 2.0 & 0.5 & 4.4 & 9.9 & 74.5 \\
\hline \multirow{2}{*}{ GRP30-Na } & 28 & 12.0 & 5.2 & 2.0 & 0.6 & 5.4 & 9.4 & 61.2 \\
\hline & 56 & 9.8 & 5.7 & 2.0 & 0.6 & 4.1 & 9.7 & 76.1 \\
\hline \multirow{2}{*}{ GRP60-Na } & 28 & 11.4 & 7.6 & 2.4 & 0.9 & 5.4 & - & 62.8 \\
\hline & 56 & 12.5 & 4.7 & 1.7 & 0.3 & 4.7 & 2.6 & 75.9 \\
\hline \multirow{2}{*}{ GRP120-Na } & 28 & 10.9 & 5.4 & 2.0 & 0.7 & 4.9 & 7.2 & 75.9 \\
\hline & 56 & 10.0 & 2.3 & 2.0 & 0.6 & 4.3 & 6.6 & 78.0 \\
\hline \multirow{2}{*}{ GRP180-Na } & 28 & 12.2 & 4.1 & 2.8 & 0.9 & 5.6 & 8.0 & 69.6 \\
\hline & 56 & 8.1 & 4.0 & 1.8 & 0.4 & 3.9 & 5.0 & 88.3 \\
\hline
\end{tabular}

analyses in the cement pastes.

All GR-modified pastes (except GRP) presented reduced portlandite content compared to REF at 28 days. The more significant reduction was observed for GRP180. The same behavior was observed for the pastes aging 56 days, with more significant reductions presented by GRP120 and GRP180. These finds are in good agreement with those observed in TG results.

In the pastes containing $\mathrm{Na}_{2} \mathrm{SO}_{4}$, the portlandite contents in the GR-modified pastes were greater than REF-Na at 28 days. At 56 days, the GR-modified pastes presented reduced Portlandite content compared to REF-Na, with a more significant difference presented by the GRP180-Na paste. It showed a positive influence of the $\mathrm{Na}_{2} \mathrm{SO}_{4}$ in later ages.

The results of portlandite consumption by the XRD suggest that the RG120 and RG180 showed improved pozzolanic reactivity on the samples. This indicates a higher reactivity of silica and alumina with calcium hydroxide by the increase in fineness of the GR.

Despite presenting a reduction in the portlandite contents, the pastes containing $\mathrm{Na}_{2} \mathrm{SO}_{4}$ showed higher levels of ettringite. This indicates a possible reaction of the portlandite with sulfate, forming ettringite. Hoang et al. (2016) argue that the rapid formation of calcium hemicarboaluminate can release sulfates (monosulfoaluminates), creating conditions for ettringite formation. The presence of calcium carbonate and the availability of alumina slows down the ettringite transformation in monosulfoaluminate.

The higher contents of hemi/monocarboaluminates in the GR-modified pastes can be explained by the presence of calcium carbonate in the used cement, which when reacting with aluminates 
can form mono/hemihydrates. These can also be formed by the ettringite decomposition (De Weerdt, et al., 2011), but it is less likely, considering that the calcite availability favors the presence of ettringite (Hoang, et al., 2016).

\subsection{Evaluation of the GR-modified cement mortars}

Table 7 shows the results of the physical characterization of the tested mortars.

\begin{tabular}{c|c|c|c|c}
\multirow{2}{*}{ Mortar } & Fresh state & \multicolumn{3}{|c}{ Hardened state } \\
\cline { 2 - 5 } & Spread $(\mathrm{mm})$ & Absorption $(\%)$ & Void index $(\%)$ & Density $\left(\mathrm{g} / \mathrm{cm}^{3}\right)$ \\
\hline REF & 210 & 7.73 & 16.14 & 2.508 \\
\hline GRM & 215 & 8.67 & 17.83 & 2.512 \\
\hline GRM30 & 232 & 8.75 & 17.89 & 2.495 \\
\hline GRM60 & 240 & 8.75 & 17.90 & 2.497 \\
\hline GRM120 & 253 & 8.53 & 17.64 & 2.515 \\
\hline GRM180 & 243 & 8.45 & 17.57 & 2.505 \\
\hline REF-Na & 210 & 7.72 & 16.31 & 2.531 \\
\hline GRM-Na & 180 & 8.36 & 17.51 & 2.533 \\
\hline GRM30-Na & 196 & 8.32 & 17.38 & 2.533 \\
\hline GRM60-Na & 182 & 8.04 & 16.82 & 2.521 \\
\hline GRM120-Na & 210 & 6.81 & 14.36 & 2.457 \\
\hline GRM180-Na & 195 & 6.55 & 13.83 & 2.445 \\
\hline
\end{tabular}

The incorporation of GR fines in the cement mortars improved the workability, suggesting a lubricating effect. This occurs due to the replacement of the water in the voids by finer GR particles. However, this effect is limited since the increase in the specific surface area leads to an increase in water demand.

Figure 5 shows the compressive strength results of the tested mortars at 28
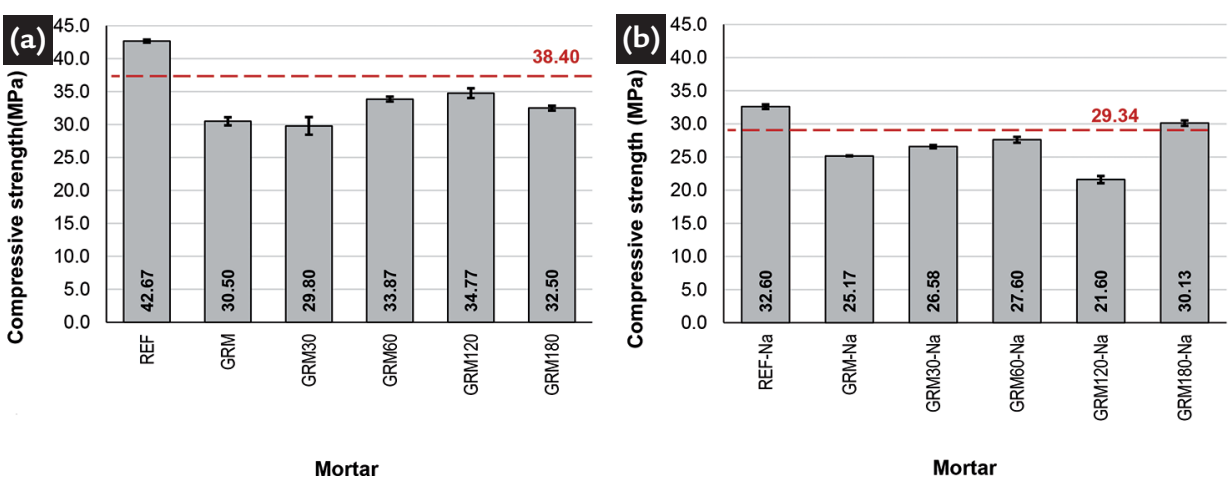

\section{Conclusions}

1. The tests performed in pastes with partial cement replacement by ground granite residue demonstrated a consumption of Portlandite and an increase in the amorphous content, indicating pozzolanic activity, especially for the residues ground for 120 and 180 minutes. However, in some specimens such as GRP, GRP 30, and GRP 60, these effects are more related to the dilution effect.

2 . The granite residues ground days and reveals that no mortars without $\mathrm{Na}_{2} \mathrm{SO}_{4}$ reached the minimum mechanical requirement of the standard NBR 12653 (ABNT, 2015) (90\% of the reference mortar compressive strength). The only mortar to reach the minimum requirement was the GRM180-Na. Overall, the mortars containing $\mathrm{Na}_{2} \mathrm{SO}_{4}$ presented the best results, showing the effectiveness of this compound in accelerating the pozzolanic

for 60, 120, and 180 minutes presented the best results in the compressive strength tests performed in mortars, but only the mortar with granite residue ground for 180 minutes and containing $\mathrm{Na}_{2} \mathrm{SO}_{4}$ reached the minimum required strength for pozzolanic materials.

3. Despite this, the mortars with the partial replacement of cement by granite residues did not present significant strength losses, and the
Table 7

Results of the physical

characterization of the tested mortars.

activity (Shi and Day, 2001; Allahverdi and Ghorbani, 2006). However, the Na${ }_{2} \mathrm{SO}_{4}$ negatively influenced the mechanical performance, since all $\mathrm{Na}_{2} \mathrm{SO}_{4}$-modified mortars presented reduced compressive strength compared to the non-modified ones. In fact, the higher amounts of alite and belite observed in the QXRD indicate impaired hydration in the composites containing $\mathrm{Na}_{2} \mathrm{SO}_{4}$.

Figure 5

Compressive strength

results of mortars at 28 days:

(a) with $\mathrm{Na}_{2} \mathrm{SO}_{4}$; (b) without $\mathrm{Na}_{2} \mathrm{SO}_{4}$.

pozzolanic activity and filler effect are pointed out as being responsible for the beneficial effect of the ground granite residues in the mortars.

4. The ground granite residue presented positive results in cementbased composites, considering the great environmental and economic benefits of its valorization and correct destination, with small losses in performance. 


\section{Acknowledgment}

Authors acknowledge the support provided by CAPES, FAPEMIG, CNPq, UFOP, UFV, UFLA. Equipment and technical support provided by UFOP laboratories NANOLAB-Redemat, and Laboratory of X-ray Diffraction Department of
Geology are gratefully appreciated. Thanks are also due to the RECICLOS-CNPq for infrastructure use and collaboration.

\section{References}

ALLAHVERDI, A., GHORBANI, J. Chemical activation and set acceleration of lime-natural pozzolan cement. Ceramics, v. 50, n. 4, p. 193-199, 2006.

ASSOCIAÇÃO BRASILEIRA DE NORMAS TÉCNICAS (ABNT). ABNT NBR 5733: High early strength Portland cement - Specification. Rio de Janeiro: ABNT, 1991.

ASSOCIAÇÃO BRASILEIRA DE NORMAS TÉCNICAS (ABNT). ABNT NBR 5752: Pozzolanic materials - Determination of the performance index with Portland cement at 28 days. Rio de Janeiro: ABNT, 2014.

ASSOCIAÇÃO BRASILEIRA DE NORMAS TÉCNICAS (ABNT). ABNT NBR 7215: Portland cement - Determination of compressive strength. Rio de Janeiro: ABNT, 1996.

ASSOCIAÇÃO BRASILEIRA DE NORMAS TÉCNICAS (ABNT). ABNT NBR 9778: Hardened mortar and concrete - Determination of absorption, voids and specific gravity. Rio de Janeiro: ABNT, 2005.

ASSOCIAÇÃO BRASILEIRA DE NORMAS TÉCNICAS (ABNT). ABNT NBR 12653: Pozzolanic materials - Specifications. Rio de Janeiro: ABNT, 2015.

BENEZET, J., BENHASSAINE, A. Grinding and pozzolanic reactivity of quartz powders. Powder Technology, v. 105, n. 1, p. 167-171, 1999.

BRASIL. Ministério de Minas e Energia (MME). Development of studies for the preparation of the duodecenal (2010-2030) plan for geology, mining and mineral processing. Brasil: Ministério de Minas e Energia/Secretaria de Geologia, Mineração e Transformação Mineral, 2009.

CERULLI, T., PISTOLESI, C., MALTES, C., SAVIONI, D. Durability of traditional plasters with respect to blast furnace slag-based plaster. Cement and Concrete Research, v. 33, n. 9, p. 1375-1383, 2003.

CINCOTTO, M. Hydration and pozzolanic reactions. In: ISAIA, G. C. (Eds.). Concrete: science and technology. São Paulo: IBRACON, 2011. 413p.

CORDEIRO, G., TOLEDO FILHO, R., TAVARES, L., FAIRBAIRN, E. Pozzolanic activity and filler effect of sugarcane bagasse ash in Portland cement and lime mortars. Cement and Concrete Composites, v. 30, n. 5, p. 410-418, 2008.

DE WEERDT, K., BEN HAHA, M., LE SAOUT, G., KJELLSEN, K., JUSTNES, H., LOTHENBACH, B. Hydration mechanisms of ternary Portland cements containing limestone powder and fly ash. Cement and Concrete Research, v. 41, n. 3, p. 279-291, 2011.

DEFÁVERI, K., NATALLI, J., SILVA, G., MENDES, J., SILVA, G., PEIXOTO, R. Rock wool waste as supplementary cementing materials for Portland cement-based composites. ACI Materials Journal, v. 115, n. 5, p. 653-661, 2018.

FANG, Y., CHANG, J. Microstructure changes of waste hydrated cement paste induced by accelerated carbonation. Construction and Building Materials, v. 76, n. 1, p. 360-365, 2015.

FLORES, Y. Produção de aditivos minerais finos a nanométricos por moagem de alta energia e avaliação de sua atividade pozolânica. Rio de Janeiro: Programa de Pós-Graduação em Engenharia Metalúrgica e de Materiais, Universidade Federal do Rio de Janeiro, 2010. 119p. (Dissertação de Mestrado em Engenharia Metalúrgica e de Materiais).

HOANG, K., JUSTNES, H., GEIKER, M. Early age strength increase of fly ash blended cement by ternary hardening accelerating admixture. Cement and Concrete Research, v. 81, p. 59-69, 2016.

IHASK, S., HASHIM, H. Low carbon measures for cement plant. Journal of Cleaner Production, v. 105, p. 260-274, 2015.

KOTAKE, N., KUBOKI, M., KIYA, S., KANDA, Y. Influence of dry and wet grinding conditions on fineness and shape of particle size distribution of production in a ball mill. Advanced Powder Technology, v. 22, n. 1, p.86-92, 2011. 
LI, G., WU, X. Influence of fly ash and its mean particle size on certain engineering properties of cement composites mortars. Cement and Concrete Research, v. 35, n. 6, p. 1128-1134, 2005.

MEHTA, P., MONTEIRO, P. Concrete: microstructure, properties, and materials. New York: McGraw-Hill, 2006. 742p.

MENEZES, R., FERREIRA, H., NEVES, G., LIRA, H., FERREIRA, H., Use of granite sawing wastes in the production of ceramic bricks and tiles. Journal of European Ceramic Society, v. 25, n. 7, p. 1149-1158, 2005.

MILLER, S. Supplementary cementitious materials to mitigate greenhouse gas emissions from concrete: can be there be too much of a good thing. Journal of Cleaner Production, v. 178, p. 587-598, 2018.

PALANIANDY, S., AZIZLI, K., HUSSIN, H., HASHIM, S. Study on mechanochemical effect of silica for short grinding period. International Journal on Mineral Processing, v. 82, n. 4, p. 195-202, 2007.

RAMOS, T., MATOS, A., SCHMIDT, B., RIO, J., SOUSA-COUTINHO, J. Granitic quarry sludge waste in motar: Effect on strength and durability. Construction and Building Materials, v. 47, p. 1001-1009, 2013.

SHI, C., DAY, R. Comparison of different methods for enhancing reactivity of pozzolans. Cements and Concrete Research, v. 31, n. 5, p. 813-818, 2001.

SOUZA, L., SANTOS, N., CAVALCANTE, A., SOUZA, L., COSTA, C. Composite utilizing residues of marble and granite for building popular home. Journal of Building Engineering, v. 9, p. 192-197, 2017.

TORRES, P., FERNANDES, H., OLHERO, S., FERREIRA, J. Incorporation of wastes from granite rock cutting and polishing industries to produce rook tiles. Journal of European Ceramic Society, v. 29, n. 1, p. 23-30, 2009.

Received: 21 January 2019 - Accepted: 6 March 2019.

(c) BY All content of the journal, except where identified, is licensed under a Creative Commons attribution-type BY. 